\title{
Effect of Tax Rates, Penalty Rate, Detection Probability, Cost of Compliance, Royalty Rates, Environmental Regulations, and Petroleum Profit Tax Compliance the Moderating Role of Trust in Government: A Conceptual Framework
}

\author{
Abba Ya'u*, Natrah Saad \& Abdulsalam Mas'ud \\ Othman Yeop Abdullah Graduate School of Business, Universiti Utara Malaysia
}

Received: 16 July 2019

Revised: 8 October 2019

Accepted: 28 October 2019

\begin{abstract}
The paper presents a theoretical framework on the moderating effect of trust in authority on the relationship between tax rates, penalty, detection probability, cost of compliance, royalty rates, environmental regulations, and petroleum profit tax compliance. The objective of the proposed framework is to expand the Allingham and Sandmo (1972) model of tax compliance by adding two more predictor variables relevant to the oil and gas industry (royalty rates and environmental regulations), and moderating variable (trust) to better explain the relationship. Allingham and Sandmo (1972) model received a lot of criticisms for not considering other non-human factors that can help in determining taxpayers' compliance behavior, hence the expansion of the model to include new variables, purely non-human factors which are relevant to the industry in question. A thorough search of the following databases: Scopus database, Web of Science, Emerald, Google Scholar, among others was conducted to come up with the relevant and related literature on the subject matter. Providing empirical evidence through validation of this framework would have important implications for policymakers in host oil and gas producing countries, oil and gas operators, the deterrence theory as well as future research.
\end{abstract}

Keywords: Trust in government, petroleum profit, tax, environmental regulation, royalty rates, compliance

\subsection{Introduction}

The current study is aimed at presenting a conceptual framework of the moderating effect of trust in government on the relationships between tax rates, penalties, detection probability, cost of compliance, royalty rates, environmental regulations, and petroleum profit tax compliance. Oil is an important source of government revenue for many

Corresponding Author. Tel: $+2348039749499,+60103158183$

E-mail: abbayau1@gmail.com 
countries around the world. The report by IMF (2012a) offers important insights on the oil contribution to government revenues across various continents. For instance, 45 per cent of government revenue comes from mining alone in Botswana; whilst one-quarter of government revenue comes from the combination of petroleum and mining in the Democratic Republic of Congo, Bolivia, Papua New Guinea, Indonesia, Vietnam and Russia (IMF, 2012a).

Furthermore, new discoveries of oil in commercial quantities have been found in Uganda and Ghana (IMF, 2012a), which highlights the possibilities of having a high percentage of government revenue from petroleum in these countries. Non-renewable natural resources are, however, found to a lesser degree but are still significant in most OECD countries, which include Australia, Norway, Canada and the UK (Boadway \& Keen, 2013). The IMF report highlighted that some developing countries were increasingly having a high percentage of revenue from petroleum of up to $80 \%$ of the total government revenue. This is the case for some Middle East countries such as Saudi Arabia, African countries such as Nigeria and Equatorial Guinea and Asian countries such as Brunei.

Evidence shows that Nigeria and Saudi Arabia charge major oil companies between 50 to $80 \%$ as petroleum profit taxes (Oremade, 2010) due to their reliance on revenues from the oil sectors. Despite the dependency on oil revenue by some developing countries, evidence points to enormous tax evasions by oil and gas companies. Nigeria is amongst the developing countries facing challenges, especially regarding petroleum profit tax noncompliance in the form of tax evasion by oil companies operating in the upstream oil sector as argued by Oremade (2010) and Ebimobowei \& Ebiringa (2012). This issue of non-compliance in developing countries, including Nigeria, makes them open for future research (Andreoni, Erard, \& Feinstein, 1998, p. 856). Thus, there is a need for an investigation of the factors influencing tax compliance amongst oil and gas companies operating in the upstream Nigerian oil sub-sector. This is desirable because the country relies on this sector for its revenue.

However, existing literature on tax compliance has not paid attention to the oil and gas sector despite its immense contribution to the economic growth of virtually all oilproducing countries. For example, in Nigeria, the oil sector contributes to about $70 \%$ of government revenue and $95 \%$ of foreign exchange earnings (Kyari, 2013). Despite the enormous contribution of oil to the economic growth of Nigeria, studies that have examined the petroleum profit tax compliance are scanty. Only one study was found during the search conducted by authors of this paper. The study was conducted by Oremede (2010) who investigated the perceptions of petroleum profit tax compliance 
from the tax administrators' point of view. The lack of tax compliance studies on the oil sector applies to most of the oil-producing countries.

Therefore, this study proposes a framework that expands Allingham and Sandmo's (1972) tax compliance, which initially originated from the seminal work of Becker (1968), to incorporate two additional predictor variables that are relevant to the oil and gas industry. These variables are royalty rates and environmental regulations, with trust in government serving as the moderating variable. If validated, the study will contribute to the existing tax compliance literature in several ways. Firstly, the Allingham and Sandmo model has not been tested or investigated in the oil and gas sector. This study will be the first to explore the power of these variables on oil and gas taxpayers.

Secondly, the model is expanded by adding two new variables which have not been tested in the tax compliance environment, therefore, it will serve as a roadmap for testing the effect of these variables on tax compliance behaviour. Thirdly, the introduction of trust in government as a moderating variable in the model will make it appear more robust and offer additional directions on how trust can stimulate the relationships between the proposed constructs (including additional variables) and the petroleum profit tax compliance. Fourthly, the current framework will further contribute to the Allingham and Sanmo's (1972) model of tax compliance which did not consider the peculiarity of tax compliance behaviour, such as incorporating non-human factors into the model as advocated by many scholars. Finally, the model, if validated, would benefit oil and gas companies and, ultimately, many host oil and gas countries through the implementation of appropriate policy measures. The next section will focus on the proposition and development of the constructs.

\subsection{Literature Review}

\subsection{Deterrence Theory}

The first economic tax compliance model was derived from the deterrence theory which was the seminal work of Becker (1968). The theory was initially built on the economics of crime approach. The theory examined the deterrent effect of threats of punishment or sanctions on unwanted or illegal behaviour. The theory postulates that the different categories of crimes committed by an individual are not due to motivation to commit the crimes but differences in the expected benefits as well as cost of committing such crimes. The theory simply implies that taxpayers are rational human beings who use available alternatives to maximise expected utility. Becker (1968) stressed that the alternative decision on the expected utility of an individual is, however, determined by the recognised possible outcomes, which, desirably, are assigned and attach the likelihoods of uncertain outcomes. 
Thus, Hamm (1995) stated that the alternative outcomes of each crime are eventually multiplied by the weighted outcomes and likelihoods, which assumes that the expected alternative utility decision will be obtained, and the utility is maximised, especially when the taxpayers select alternative decisions that give the most favourable expected utility. Extant literature has categorised deterrence into two groups: specific and general deterrence. Jacson, and Millron (1986) argued that research on tax compliance behaviour have mostly focused on general deterrence, which simply means the deterrent effect of potential sanctions, whilst specific deterrence refers to the deterrent effect of actual actions. Consequently, Allingham and Sandmo were the first researchers to use the deterrence theory in the taxpayer's compliance behaviour and came up with what we refer to as the A-S model, which was based on Becker's (1968) economics of crime model. The model is what this study intends to expand. Figure 1. depicts the model.

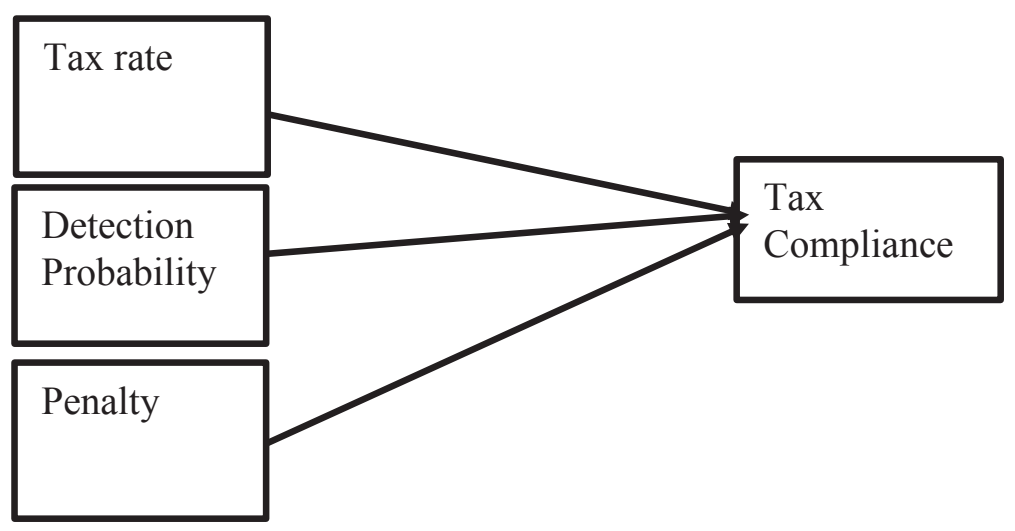

Sources. Allingham and Sandmo (1972)

Figure 1

Accordingly, Allingham and Sandmo (1972) argued that the decision of rational taxpayers to evade tax or comply is based on the taxpayer's choice on risk and uncertainty. According to Allingham and Sandmo, under the deterrence theory, the compliance decision of taxpayers is the function of three variables, namely tax rate, penalty, and probability of detection as depicted in Figure 1 above. It can be mediated by the cost of compliance (Fischer, et al., 1992), hence the introduction of the cost of compliance into the model. The expanded deterrence theory by Fischer is depicted in Figure 2 below. 


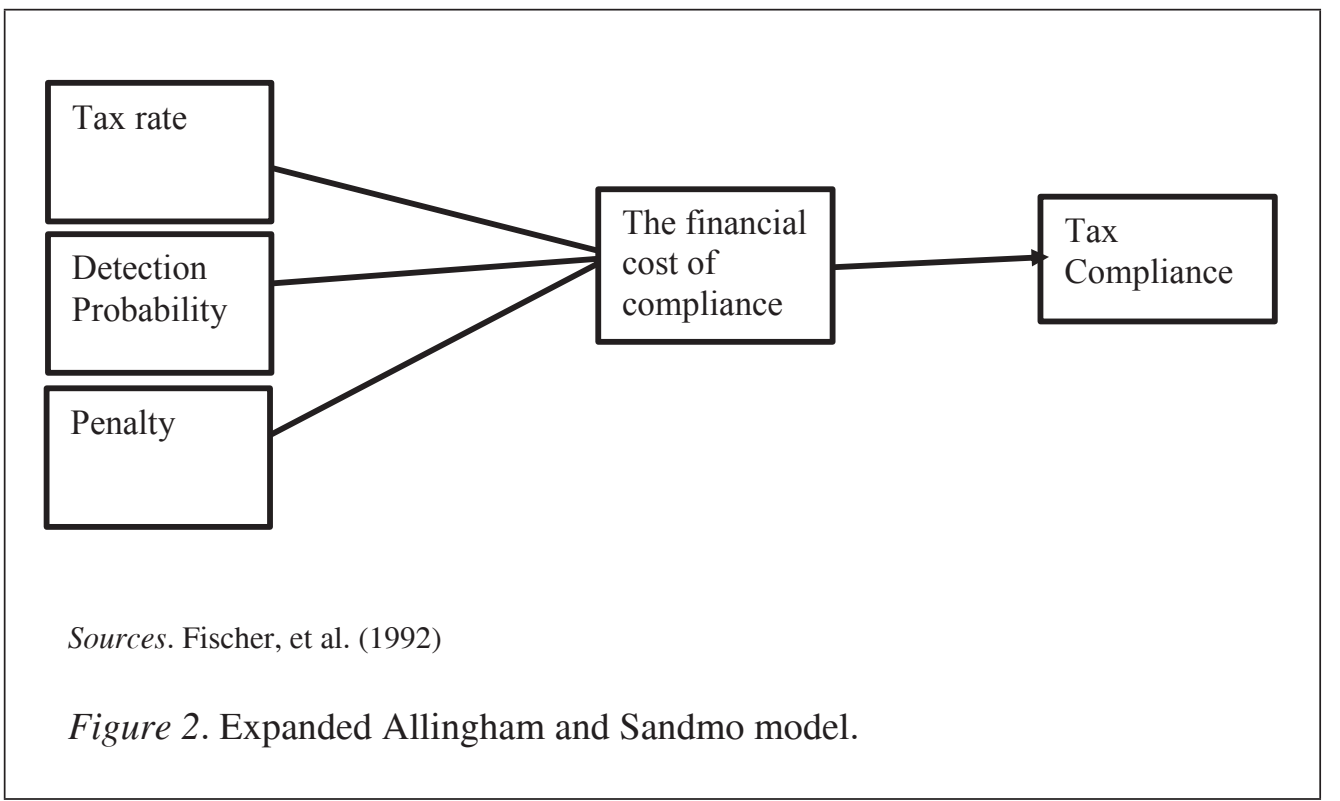

\subsection{Petroleum Profit Tax}

Oremade (2006) noted that the Petroleum Profit Tax is charged to the companies operating in the Nigerian oil sector on the value of oil sales at the price prevailing in the world oil market. Moreover, crude oil and gas sales for local refining are valued at the actual amount realised for petroleum profit tax, and the value of oil sales at the global oil market is compared with the prevailing value at the posted price; where the posted price is greater, the tax is charged at the posted price (Gbegi, et al., 2017). Petroleum tax refers to the tools and machinery of government used to create more essential rent sharing balance between host government and oil and gas companies, and the Nigerian petroleum profit tax is a clear example of petroleum taxation (Amiesa, Omowunmi, \& Joseph, 2018). The Petroleum Profit Tax (hereafter, PPT) is defined as the direct tax imposed annually on the chargeable profit of petroleum taxpayers, conducting petroleum exploration and production activities, and also serves as the instrument used for getting revenue from hydrocarbon wealth by the host country (Evans \& Hunt, 2011). The petroleum profit tax is a tax related to upstream oil operations in the Nigeran oil industry (Odusola, 2006).

Generally, the PPT is associated with a profit-sharing element on oil exploration; oil mining; and oil prospecting leases, rents, and royalties (Gbegi, et al., 2017). The PPT refers to the charging of taxes on the profits accrued in the course of oil operation in Nigeria (Nwezeaku, 2005). The petroleum profit tax is assessed from the profits of the companies engaged in oil operation for the prevailing accounting period, normally from January to December (Anyawu, 1993). Therefore, the current study aims at exploring 
the effects of tax compliance variables on petroleum taxpayers, which is quite new and unique in the tax compliance environment. The Petroleum Profit Tax is currently at $50 \%$ for operations in the deep offshore and inland basin, whilst the rate is $85 \%$ for operations in the onshore and shallow waters in Nigeria (PPTA, 2004 As amended). Moreover, the PPT serves as the dependent variable in the proposed framework of this study.

\subsection{Trust in Authority}

To logically ground our prediction, this section will explain the role of trust in authority in moderating the proposed unique interaction effects of the deterrence theory variables on petroleum profit tax compliance. Trust could be regarded as the ability and willingness to be exposed to the activities of other parties based on the anticipation that the other party will do a particular act vital and significant to the trustor, regardless of the capability to control or monitor the other party (Mayer, Davis, \& Schoorman, 1995). Consequently, taxpayers who recognise the tax authority as being trustworthy are likely to trust it and this may invariably increase compliance (Murphy, 2004). Additionally, Kirchler, et al. (2008) argued that trust is one of the significant factors that shape compliance. Driving from the work of Kirchler, et al. (2008) on the slippery slope framework which proposed two forms of compliance: enforced and voluntary tax compliance, it was concluded that voluntary tax compliance is driven by trust in authorities. In line with Kirchler, et al. (2008), it was asserted by Gangl, Hofmann, and Kirchler (2015) and Hofmann, et al. (2014), in separate studies, that trust leads to tax compliance.

Though trust in government has been found to be one of the factors of tax compliance, the trust relationship between the authorities and the taxpayers is still considered in the context of "cops and robbers" in developing countries (Kastlunger, et al., 2013; Muehlbacher, Kirchler, \& Schwarzenberger, 2011). Notwithstanding, even in the developed nations, the demand for tax compliance by authorities is seen as a burden that lowers business profits (Alm, Kirchler, \& Muehlbacher, 2012; Alm \& McClellan, 2012; and Torgler, 2011). Trust is important in shaping compliance, because most of the taxpayers evaluate whether the authorities (Trustees) pursue objectives that are vital to them (Gangl, et al., 2015; Gangl, et al., 2012).

Therefore, trust should be an emotion directed towards other parties and it should go beyond just logical evaluation and include genuine care and concern (Johnson \& Grayson, 2005; Schaubroeck, Lam, \& Peng, 2011). Trust is unarguably playing a significant and influential role in shaping the relationships between taxpayers and authorities, especially where government performance convinces the taxpayers to view their authorities as being capable and concerned for their wellbeing (Gobena, \& Van 
Effect of Tax Rates, Penalty Rate, Detection Probability, Cost of Compliance, Royalty Rates, Environmental Regulations,

and Petroleum Profit Tax Compliance the Moderating Role of Trust in Government: A Conceptual Framework

A Conceptual Model: 71-92

Dijke, 2016). Based on these debates, we have argued that trust in authorities will moderate the relationships between taxpayers and tax compliance.

\subsection{Tax Rates}

The tax rate could be regarded as the actual rate of taxes on which the taxpayers are anticipated to pay out of their taxable profit to relevant tax authorities. It has been argued that significant interest has been shown on corporate income tax reforms which eventually widens the base and lowers the tax rates (Gravelle, 2011). Subsequently, many scholars have examined the influence of tax rate on tax compliance; for example, Mas'ud, et al. (2014) used simple regression to examine the influence of tax rate on tax compliance in Africa within the period of 2012 to 2013. The study covered 61 African countries, and the result indicate a significant negative effect of tax rates on tax compliance.

However, their findings have limited validity in other sectors, such as petroleum sectors; for this reason, they may not be a good yardstick in determining the actual effects of the variables. Furthermore, a higher tax rate does not essentially imply high tax compliance, hence tax payments depend on the tax base (Vintila, Gherghina, \& Paunescu, 2018). Subsequently, Gius (2018) examined the relationship between tax rate and tax revenue. He argued that there is a level of tax rate at which tax revenues are maximised. Gius, further asserted that, at a high marginal rate, the relationship is inverse because high tax rates may restrain economic activities and decrease the supply of labour.

Clotfelter (1983) and Slemrod (1985) investigated marginal tax rates and found that marginal tax rates have a significant effect on underreporting. Additionally, Bayer (2006) found that higher tax rates increase evasion. Wang, et al. (2018) found a positive relationship between effective tax rates and CEO promotion. Similarly, Freindland, Maital, and Rutenberg (1978); Collins and Plumlee (1991); Alm, Jackson, and McKee (1992); and Park and Hyun (2003), in a laboratory experiment using differential tax rates, found that increases in tax rates led to higher evasion. Contrary to the findings which postulated that an increase in tax rates may lead to higher tax evasion, some studies indicated opposite findings. For instance, Alm, Sanchez, and Dejuan (1995); and Mas'ud et al. (2014) found negative relationships between increase in tax rates and evasion.

Based on the empirical findings above the following proposition was developed.

P1 There is a negative relationship between tax rates and petroleum profit tax compliance. 
Deterrence models of tax compliance behaviour predict that an increase in tax rates will increase compliance (Allingham \& Sandmo, 1972; Alm, Sanchez, and Dejuan, 1995; and Mas'ud et al., 2014). On the contrary, studies of other researchers on tax rate found that higher tax rates decrease compliance, for example, Pommerehne and WeckHannemann (1996); Weck-Hannemann and Pommerehne (1989); Clotfelter (1983); Slemrod (1985) Bayer (2006); Freindland, et al. (1978); Collins and Plumlee (199); Alm, et al. (1992); and Park and Hyun (2003). Baron and Kenny (1986) argued that where there are mixed findings on the relationships between constructs, a moderating variable can be integrated to stimulate the relationship, therefore, based on the mixed findings above the following proposition was drawn.

$\boldsymbol{P} 2$ Trust in government will moderate the relationship between tax rates and petroleum profit tax compliance, such that the relationship will be weaker or strengthened for the companies that have trust in government.

\subsection{Penalty Rate}

Penalties refer to the negative punishment of paying money on those who violate the rules and regulations (Savitri, 2016). Savitri further argued that there are two types of tax penalties in tax laws: the criminal sanction and the administrative sanction. The administrative sanction is imposed when taxpayers violate administrative rules and regulations, as such, taxpayers pay penalties and or interest, whilst the criminal sanction is likely to be a jail sentence or prison. Additionally, a penalty is considered as the preventive measures employed by the tax authority on taxpayers (Devos, 2013). Furthermore, Gordon and Wen (2018) examined tax penalties on fluctuating incomes, using longitudinal data in Canada. The study used longitudinal data to estimate the tax penalties in the six panels of Canadian data from 1993 to 2010. The result suggested that the tax penalty in recent times is lower than in the mid-90s essentially as a result of a decrease in marginal tax rates and that the tax penalty is insignificant for most taxpayers but remains consequential for many. The results further revealed that 10 per cent of the taxpayers faced annual tax penalties between the period of 2005-2010, nearly 1 per cent of their incomes, and also the tax penalties were ultimate at the lower end of the income range of the autonomous self-employed. Nevertheless, empirical evidence on the relationship between penalty and tax non-compliance indicates a positive relationship between the two variables; for example, Virmani (1989) found a positive relationship between higher tax penalty rate and tax non-compliance, and further argued that imposing higher penalty rates may have induced taxpayers to behave dishonestly. Additionally, Lee (2015) argued that the imposed penalty has an indirect effect on tax evasion.

Doran (2009) found that penalty may encourage evasion. Furthermore, Sinnasamy and Bidin (2017) found that there is a positive relationship between a penalty and tax non- 
Effect of Tax Rates, Penalty Rate, Detection Probability, Cost of Compliance, Royalty Rates, Environmental Regulations,

and Petroleum Profit Tax Compliance the Moderating Role of Trust in Government: A Conceptual Framework

A Conceptual Model: 71-92

compliance. Similarly, Balassone and Jones (1998) argued that the penalty reduces the possibility of higher tax evasion. Savitri (2016) found a positive relation between penalty and tax compliance through the mediation effect of service quality. The right and acceptable penalty being in place will lead to efficient tax administration which may influence tax compliance. Additionally, none of the studies available examined the influence of tax penalties in the oil and gas sectors despite the influential effect of penalties in determining compliance as argued by Allingham and Sandmo (1972) and Fischer, et al. (1992), where both of these studies postulated that penalty could lead to tax compliance. Therefore, this study utilized the variable to determine whether it could lead to PPT compliance or non-compliance in the oil and gas sector, hence the development of the following proposition.

P3 There is a positive relationship between penalty rate and petroleum profit tax compliance.

Extant literature on tax penalties demonstrated inconsistent findings which may be contextual, sectorial or even methodological. Therefore, this could be one of the reasons that require further investigation of the variables. Following Barron and Kenny (1986) who emphasize the need for introducing moderating variables once mixed findings exist, the following proposition was drawn.

$\boldsymbol{P} 4$ Trust in governments will moderate the relationship between penalty rate and petroleum profit tax compliance, such that the relationship will be strengthened or weaker for the companies that trust the government.

\subsection{Detection Probability}

Probability of detection is defined by Chau and Leung (2009) as the possibility that the tax authority can discover tax non-compliance by taxpayers. Furthermore, the probability of detection has received considerable attention from many scholars. For example, Alm, Martinez-Vasquez, and Schneider (2004) emphasised that the probability of detection has a significant double deterrent effect on taxpayers. The central argument here is that, the nexus is what they refer to as the direct deterrent effect of taxpayers that are being audited as well as the indirect effect of taxpayers that are not being audited. They further stated that, as the probability of detection becomes higher, it may or may not encourage tax compliance. As stated in Kirchler (2007), a survey study by Mason and Calvin (1978) stressed that tax evaders always regard the chance of being detected as low.

Palil and Mustapha (2011) examined, using multiple regression, the determinants of tax behaviour in Malaysia. Through the employment of a survey of 1,073 taxpayers, the found that when taxpayers assumed that they would not be detected as a result of an 
insufficient investigation, they embarked on tax evasion strategy using less detectable documentation to pay less tax. Notwithstanding, the probabilities of detection may invariably encourage some taxpayers to declare their true income and, eventually, may increase compliance. Allingham and Sandmoh (1972) submitted that an increase in probability of detection will, eventually, always lead to a greater income being declared. Empirical evidence on the influence of the probability of detection on tax compliance revealed mixed and inconsistent findings. For instance, Alm (1991) found a positive relationship between the probability of detection and tax compliance. Additionally, Mason and Calvin (1978), in their research using a survey, indicated that evading taxpayers perceived the chances of being caught lower than honest taxpayers. On the other hand, Young (1994) and Slemrod, et al. (2001), in different studies, showed that detection probability was found to be an important determinant of a taxpayer's compliance. Though, they reported that probabilities of detection were negatively correlated with compliance behaviour. Based on the mixed empirical findings above and the adaption of Barron and Kenny's assertion on the moderating variable, the following proposition was established.

P5 There is a positive relationship between detection probability and petroleum profit tax compliance.

P6 Trust in government will moderate the relationship between the probability of detection and petroleum profit tax compliance, such that the relationship will be strengthened or weaker for the companies that trust the government.

\subsection{Tax Compliance Cost}

Compliance cost refers to the cost incurred by a taxpayer as a result of fulfilling his/her tax obligations separately from the tax liability (Main, 2012). Additionally, compliance cost is the aggregate of the cost incurred by taxpayers in addition to their tax liabilities, in achieving the taxation requirements (Rahmawati, as cited in Savitri, 2016). Tax compliance costs refers to the costs that are incurred by third parties or taxpayers, above the normal tax liabilities in a quest to meet the requirements of the tax system (Godwin, 1978). Johnstons (1961) defined corporate tax compliance cost "as the reduction in operating costs, exclusive of the tax itself, which may result if the federal income tax where eliminated" (Godwin, 1978, pg 391).

Haig (1935) who mailed a questionnaire to 1600 members of the American Management Association (AMA) found that high compliance cost was related to low administrative cost, and finally argued that there is a nexus between compliance and administrative cost. However, Stamatopoulos, Hadjidema, and Eleftheriou (2017) found corporate tax compliance costs of considerable size and differing with numerous companies' unique characteristics, which included other companies' locations, legal forms, and sectors 
Effect of Tax Rates, Penalty Rate, Detection Probability, Cost of Compliance, Royalty Rates, Environmental Regulations,

in which they operated. Eichfelder and Kegels (2014) found empirical evidence that tax authorities are one of the significant costs drivers which give rise to taxpayers' tax administration cost to reach up to $25 \%$. It is, however, important to note that there is limited empirical evidence on the relationship between compliance cost and tax compliance as argued by Abdul-Jabbar (2009) as most studies highlight the magnitudes of compliance cost in terms of values.

Consequently, few empirical studies on tax compliance cost concerning tax compliance were found by Abdul-Jabbar \& Pope (2008); Abdul-Jabbar (2009); Sapiei \& Abdullah (2014); and Adam \& Yusof, (2018). The size of compliance cost and compliance behaviour shows no statistical significance (Abdul-Jabbar \& Pope, 2008). Based on the findings above and the non-availability of empirical evidence on the relationship between the cost of compliance and tax compliance in the oil and gas sector, the following proposition was developed.

$P 7$ There is a negative relationship between compliance cost and petroleum profit tax compliance.

Empirical evidence on the relationship between tax compliance cost and tax compliance is scanty in existing literature. However, the few available ones showed mixed findings; for instance, Sapiei, et al. (2017) found a positive relationship between tax compliance cost and goods and services tax (GST) in Malaysia. Compliance costs were found not to influence SME's tax non-compliance in Malaysia (Abdul-Jabbar, 2009). On the contrary, other studies found tax compliance cost to have a significant negative impact on GST non-compliance (Xin, et al., 2015; Faridy, et al., 2014; Nzioki \& Peter, 2014; and Adam \& Yusof, 2018). Based on the inconsistent findings above, and following Barron and Kenny (1986), who stated that where there is the existence of inconsistent findings, a moderating variable can be introduced to stimulate the relationship, the following proposition was developed.

P8 Trust in government will moderate the relationship between compliance cost and petroleum profit tax compliance, such that the relationship will be strengthened or weaker for the companies that trust the government.

\subsection{Royalty Rates}

Royalty refers to the share of production emanating from lease contracts between the rightful owner of the oil and gas or other mineral resources, in other words called the "lessor", and the "lessee" who is given the right to use the lands for the development of mineral resources. In return for granting the lessee the rights to explore the mineral resources, the lessee gives a share of the mineral of any kind produced or a royalty to the lessor (Carr \& Owen, 1997). On the other hand, investors participate in royalties 
through production, and most investors extend their interests through demands to adjust the royalty rates to suit them and warn that any attempt to increase royalty rates may discourage investment (Onifade, 2017). Moreover, concerning changes in production relating to royalty, Gowharzad and Al-Harthy (2011) argued that there will be a higher royalty rate as production increases, therefore, the government will eventually benefit from an increase in production and also charge lower royalty rates as production decreases. Though the relationship between royalty rates and petroleum profit tax compliance has not been critically investigated, studies are available that indicate the significance of studying the sector as well as the variables concerning taxation which could serve as the basis for forming the hypotheses. For example, Kemp (1992) examined the effectiveness and efficiency of the petroleum fiscal regime in Norway, the Netherlands, Denmark, and the UK in collecting natural resources tax (economic rents), from the development of new fields associated with uncertainty related to development costs and oil prices. In a similar vein, Osmundsen (1998) established a model of dynamic non-renewable resources taxation.

Dismukes, Bueke, and Mesyanzhinov (2006) reiterated that, an evolving challenge facing several energy-producing countries will be an establishment of policies that encourages sustained economic development of growing oil and gas properties, especially since under royalty relief scenarios an increasing amount of revenue is realised by the states. Furthermore, Boyd and Khowsrow (1994) investigated how energy cuts to balance with income tax increased the effect of consumption, production, and welfare in the Philippines. They concluded that energy tax cuts improved the energy sector though it decreased the manufacturing sector's output irrespective of the level of energy tax reduction. Interestingly, this corresponded with the earlier empirical evidence which reported taxation's impact on the economics of natural resources (Isehunwa \& Uzoalor, 2011).

Based on the above evidence which, eventually, highlighted the importance of natural resources tax in the state's economic development, as well as how the connections of natural resources tax, such as royalty to the mainstream of taxation, is very significant, and also the lack of existing studies that test the influence of royalty rates on petroleum profit tax compliance, the following proposition was developed.

\section{P9 There is a relationship between royalty rates and petroleum profit tax compliance}

The empirical literature on the relationship between royalty rates and natural resources tax is scanty. However, some empirical studies are available that indicated the nexus between royalty rate and natural resources taxation. For example, Kemp (1992) examined the effectiveness and efficiency of the petroleum fiscal regime in Norway, the Netherlands, Denmark, and the UK in collecting natural resources taxes (economic rents \& royalty) from the development of new fields associated with uncertainty related to development costs and oil prices. Dismukes, Bueke, and Mesyanzhinov (2006) 
Effect of Tax Rates, Penalty Rate, Detection Probability, Cost of Compliance, Royalty Rates, Environmental Regulations,

and Petroleum Profit Tax Compliance the Moderating Role of Trust in Government: A Conceptual Framework

A Conceptual Model: 71-92

reiterated that an evolving challenge facing several energy-producing countries will be the establishment of policies that encourage the sustained economic development of growing oil and gas properties, especially since under royalty relief scenarios, an increasing amount of revenue is realised by the states.

Furthermore, Boyd and Khowsrow (1994) investigated how energy cuts to balance with income tax increase affect consumption, production, and welfare in the Philippines. They concluded that energy tax cuts improved the energy sector though it decreased the manufacturing sector's output irrespective of the level of energy tax reduction. Interestingly, this corresponded with the recent empirical evidence which reported taxation's impact on the economics of natural resources (petroleum tax and royalty) (Isehunwa \& Uzoalor, 2011). A transparent tax system provided by tax authorities might greatly influence the relationship between royalty payments and petroleum profit tax compliance. Based on this assertion, the current study has argued that trust in authorities will stimulate the relationship between royalty payments and petroleum profit tax compliance.

P10 Trust in authorities will moderate the relationship between royalty rate and petroleum profit tax compliance, such that the relationship will be weakened or strengthened for the companies that trust the government.

\subsection{Environmental Regulations}

Environmental regulations refer to the use of urban and natural socio-economic and physical environments in the service of regulations (Korpela, et al., 2018). The view from traditional economics states that, strict environmental regulations may restrict the technological novelty of a company (Lankoski, 2017). Additionally, environmental regulations will restrict the effectiveness and efficiency of technological modernisations and, subsequently, reduce the efficiency of the manufacturing sector through empirical analysis (Leeuwen \& Mohnen, 2013; Zhao \& Sun, 2016). Moreover, Guo, Xia, Zhang, and Zhang (2018) argued that environmental regulations cause pressure on the company's behaviour which may result in an increase in environmental cost and may eventually affect the company's profitability. Other scholars, such as Feichtinger, Hartl, Kort, and Veliov (2005), stressed that strict environmental regulations targeted at reducing emissions mostly have a significant effect on industrial development. Based on the above debate, it is important to note that environmental regulations affect the costs of production of companies as well as profits, which may affect taxes. This further highlights the importance of investigating the effect of this variable on taxpayers.

Nevertheless, empirical evidence regarding the relationship between environmental regulations and petroleum profit tax is not available and this study appears to be the first of its kind to test the relationships between the variables in question. As such, other 
studies on environmental regulations that are related to the variable will be reviewed to serve as the basis for the hypothesis's development. For example, Cerqueti and Coppier (2014), whose study on the issue of evasion and environmental policies suggested that environments are affected by numerous economic factors, referred to the economic factors as needing to include environmental inspectors (regulators and tax inspectors) and polluting firms (taxpayers).

Thus, several scholars concentrated on the impact of human activities on pollution and natural resources, technological processes, and energy consumption (Bosetti, Messina, \& Valente, 2002; Tapiero, 2009; and Cerqueti, 2014). Consequently, Song, Wang, and Sun (2018) examined the relationships amongst environmental regulations, green technology and profit in manufacturing amongst 1,197 firms in China between 2008 to 2015. They found that environmental regulations moderated the relationship between green technology and the profit of manufacturing firms. Based on the above evidence and the lack of studies that empirically tested the relationship between environmental regulations and petroleum profit tax compliance, the following proposition was developed.

\section{P11 There is a relationship between environmental regulations and Petroleum Profit Tax Compliance}

A few studies have examined the influence of environmental regulations on different aspects of human, political, and economic systems. For instance, Zhao, et al. (2018) investigated whether environmental regulations undermine an energy firm's performance, and using event study methodology, the study found environmental regulations to have several effects on the stock price of China's listed fossil-based energy firms. Other findings revealed that environmental regulations have great but negative effects on listed fossil-based energy firms that have a higher level of Environmental Information Disclosure (EID) than firms with a lower level of EID, which invariably poses great challenges to policymakers in designing relevant and appropriate environmental policies.

Additionally, Cheng and Liu (2018) examined the effects of public attention on the environmental performance of most polluting companies in China. Using big data from web searches, the result found that companies which are open to a high level of public attention have better environmental performance. Furthermore, employing a quasi-experiment in China, Zhang, Chen, and Guo (2018) investigated whether central supervision enhances local environmental enforcement. The result revealed that central supervision considerably decreased industrial Chemical Oxygen Demand (COD) emission by almost $26.8 \%$, which highlighted the need for improvement in China's environmental regulations using central supervision. On the other hand, an empirical 
Effect of Tax Rates, Penalty Rate, Detection Probability, Cost of Compliance, Royalty Rates, Environmental Regulations,

and Petroleum Profit Tax Compliance the Moderating Role of Trust in Government: A Conceptual Framework

A Conceptual Model: 71-92

exploration study on environmental regulation and green skills was conducted by Vona, et al. (2018) and the result indicated that changes in environmental regulations were found to not affect the overall employment. Based on the empirical findings above the following preposition was developed.

$P 12$ Trust in government will moderate the relationship between environmental regulations and petroleum profit tax compliance, such that the relationship will be weakened or strengthened for the companies that trust the government.

\subsection{Proposed Conceptual Framework}

Following the literature discussed above, Figure 3 shows the theoretical framework which depicts the direct as well as indirect relationships of the constructs under consideration.

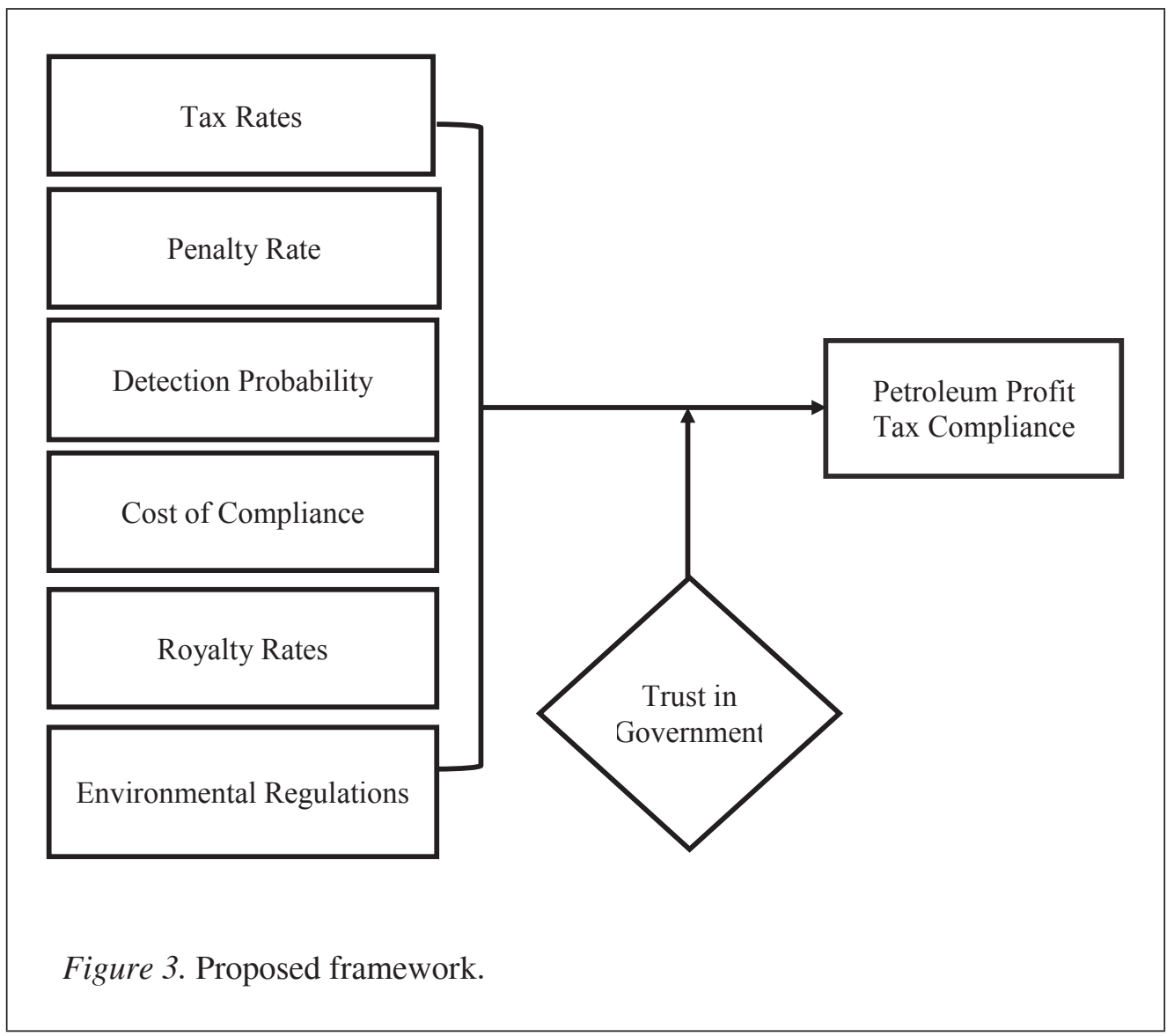




\subsection{Conclusion/Policy Implication}

The paper discussed the moderating effect of trust in government on the relationships between the tax compliance variables of Allingham and Sandmo (1972) and petroleum profit tax compliance. All the variables comprised tax rates, penalties, detection probability, and compliance cost, which were expanded with two more predictor variables relevant to the oil and gas industry (royalty rates and environmental regulations), moderating variable (trust in government) and petroleum profit tax compliance as depicted in Figure 1 above. The paper argued that trust in government can moderate the relationships between the constructs in the framework and the explained variable (petroleum profit tax compliance). Additionally, the study can benefit the international tax authorities generally and the Nigerian tax authority in particular. The study will help the tax authorities in developing and administering tax laws and policies to reduce tax evasion and increase the overall level of corporate tax compliance with particular reference to petroleum companies. Moreover, it will provide insight into the regulatory agencies as regards the appropriate tax system to be used in their respective countries which will be friendlier to both government and oil operators. The study will serve as evidence for the regulatory agencies to offer an appropriate recommendation to the government for the need to restructure the existing tax system for the betterment of both the government and the oil companies.

Thirdly, the study will also be beneficial to other countries having abundant natural resources in a number of ways: the study will help other countries to come up with more robust tax structures capable of increasing PPT compliance. The study will help those countries in designing simple tax systems that will increase compliance, especially in the area where similarities exist amongst the countries. Fourthly, the study will be of great importance to the larger academic environment. Petroleum taxation has not been critically investigated using the tax compliance model. From the contextual perspective, the study will provide empirical evidence on the determinants of the PPT in Nigeria. Thus, it will provide a roadmap for other researchers interested in investigating the relationships between tax compliance variables and petroleum profit tax compliance amongst oil companies in other countries around the globe.

The framework will expand the existing economic deterrence theory by adding two more predictor variables (Royalty rate $\&$ environmental regulations) and a moderating variable (Trust in government), thereby contributing theoretically to the tax compliance literature. The model is in the process of validation, if validated empirically, some policy insights can be offered to the oil and gas host countries which can benefit the government, oil operators and by extension any other potential investors willing to embark in oil and gas activities around the globe. 
Effect of Tax Rates, Penalty Rate, Detection Probability, Cost of Compliance, Royalty Rates, Environmental Regulations,

and Petroleum Profit Tax Compliance the Moderating Role of Trust in Government: A Conceptual Framework

A Conceptual Model: 71-92

\section{Acknowledgment}

One of the authors wishes to acknowledge the scholarship award to Universiti Utara

Malaysia by Petroleum Technology Trust Fund (PTDF).

\section{References}

Abdul-Jabbar, H. (2009). Income tax non-compliance of small and medium enterprises in Malaysia: Determinants and tax compliance costs (Doctoral dissertation, Curtin University).

Abdul-Jabbar, H., \& Pope, J. (2008). Exploring the relationship between tax compliance costs and compliance issues in Malaysia. Journal of Applied Law and Policy, (2008).

Adam, M. N. H., \& Yusof, N. A. M. (2018). A comparative study on the burden of tax compliance costs amongst GST registered companies in Malaysia and abroad. Journal of Science, Technology and Innovation Policy, 3(2).

Allingham, M. G., \& Sandmo, A. (1972). Income tax evasion: A theoretical analysis. Journal of Public Economics, 1, 323-338.

Alm, J. (1991). A perspective on the experimental analysis of taxpayer reporting. The Accounting Review, 66(3), 577-593.

Alm, J., Jackson, B. R., \& McKee, M. (1992). Estimating the determinants of taxpayer compliance with experimental data. National Tax Journal, 45(1), 107-114.

Alm, J., Martinez-Vazquez, J., \& Schneider, F. (2004). 'Sizing' the problem of the hard-to-tax. Paper presented at the Hard to Tax: An International Perspective, Andrew Young School of Policy Studies, Georgia State University, Stone Mountain, May 15-16, 2003.

Alm, J., Sanchez, I., \& De Juan, A. (1995). Economic and noneconomic factors in tax compliance. Kyklos, 48(1), 1-18.

Alm, J., Kirchler, E., \& Muehlbacher, S. (2012). Combining psychology and economics in the analysis of compliance: From enforcement to cooperation. Economic Analysis and Policy, 42(2), 133-151.

Alm, J., \& McClellan, C. (2012). Tax morale and tax compliance from the firm's perspective. Kyklos, 65(1), 1-17. doi: 10.1111/j.1467-6435.2011.00524.x

Amiesa, F. S., Omowunmi, I., \& Joseph, A. A. (2018). Economic evaluation of the dual petroleum tax system proposed in the 2017 Nigeria Fiscal Reform Framework. In SPE Nigeria Annual International Conference and Exhibition. Society of Petroleum Engineers.

Anyanwu, J.C. (1993). Monetary economics: Theory, policy and institutions, Onitsha: Hybrid Publishers.

Balassone, F., \& Jones, P. (1998). Tax evasion and tax rates: Properties of a penalty structure. Public Finance Review, 26(3), 270-285. 
Bayer, R. C. (2006). A contest with the taxman-the impact of tax rates on tax evasion and wastefully invested resources. European Economic Review, 50(5), 10711104.

Becker, G. S. (1968). Crime and punishment: An economic approach. Journal of Political Economy, 76(2), 169-217.

Bosetti, V., Messina, E. \& Valente, P. (2002). Optimization technologies and environmental applications. IMAJ. Manag. Math., 13, 167-185.

Boyd, R.G. and D. Khosrow, (1994). Tax reform and energy in the Philippines economy: A general equilibrium computation. Energy Journal, 15(2).

Carr, W. F., \& Owen, P. R. (1997). Clear as crude: Defending oil and gas royalty litigation. Natural Resources Journal, 37(3), 695-706.

Cerqueti, R. (2014). Exhaustion of resources: a marked temporal process framework. Stochastic environmental research and risk assessment, 28(4), 1023-1033.

Cerqueti, R. and Coppier, R. (2009), “Tax revenues, fiscal corruption and 'shame' costs", Economic Modelling, 26(1/2), 1239-1244.

Chorvat, E., \& Chorvat, T. R. (2018). The dynamic stability of progressive taxation. National Tax Journal, 71(1).

Clotfelter, C. (1983). "Tax evasion and tax rates: An analysis of individual returns." Review of Economics and Statistics 65, 363-373.

Collins, J. H., \& Plumlee, R. D. (1991). The taxpayer's labor and reporting decision The effect of audit schemes. Accounting Review, 66(3), 559-576.

Devos, K. (2013). Do penalties and enforcement measures make taxpayers more compliant? The view of Australian tax evaders. Far East Journal of Psychology and Business, 12(1), 1-9.

Dismukes, D. E., Burke, J. M., \& Mesyanzhinov, D. V. (2006). Estimating the impact of royalty relief on oil and gas production on marginal state leases in the US. Energy policy, 34(12), 1389-1398.

Doran, M. (2009). Tax penalties and tax compliance. Harv. J. on Legis., 46, 111.

Eichfelder, S., \& Kegels, C. (2014). Compliance costs caused by agency action? Empirical evidence and implications for tax compliance. Journal of Economic Psychology, 40, 200-219.

Evans, J. \& Hunt L. (2011). International handbook on the economics of energy. Massachusetts, USA: Edward Elgar Publishing Inc. USA. ISBN 978085793 8251 experimental approach. Journal of Business Ethics, 18(2), 173-184.

Feichtinger, G., Hartl, R. F., Kort, P. M., \& Veliov, V. M. (2005). Environmental policy, the Porter hypothesis and the composition of capital: Effects of learning and technological progress. Journal of Environmental Economics and Management, 50(2), 434-446.

Fischer, C. M., Wartick, M., \& Mark, M. M. (1992). Detection probability and taxpayer compliance: A review of the literature. Journal of Accounting Literature, 11(1), $1-46$. 
Effect of Tax Rates, Penalty Rate, Detection Probability, Cost of Compliance, Royalty Rates, Environmental Regulations,

and Petroleum Profit Tax Compliance the Moderating Role of Trust in Government: A Conceptual Framework

A Conceptual Model: 71-92

Friedland, N., Maital, S., \& Rutenberg, A. (1978). A simulation study of income tax evasion. Journal of Public Economics, 10(1), 107-116.

Faridy, N., Copp, R., Freudenberg, B., \& Sarker, T. (2014). Complexity, compliance costs and non-compliance with VAT by small and medium enterprises (SMEs) in Bangladesh: Is there a relationship? Retrieved from http://hdl.handle. net/10072/63522

Gangl, K., Hofmann, E. B., Pollai, M., \& Kirchler, E. (2012). The dynamics of power and trust in the 'slippery slope framework' and its impact on the tax climate. Available at SSRN 2024946.

Gangl, K., Hofmann, E., \& Kirchler, E. (2015). Tax authorities' interaction with taxpayers: A conception of compliance in social dilemmas by power and trust. New Ideas in Psychology, 37(0), 13-23. doi: http://dx.doi.org/10.1016/j. newideapsych.2014.12.001

Gbegi, D., Adebisi, J., \& Tosin, B. O. D. U. N. D. E (2017). The Effect of Petroleum Profit Tax on the Profitability of Listed Oil and Gas Companies in Nigeria

Gius, M. (2018). The Relationship between Tax Rates and Tax Revenue. Atlantic Economic Journal, 46(1), 137-139.

Gobena, L. B., \& Van Dijke, M. (2016). Power, justice, and trust: A moderated mediation analysis of tax compliance among Ethiopian business owners. Journal of Economic Psychology, 52, 24-37.

Godwin, M. (1978). Compliance costs-The cost of paying tax. Omega, 6(5), 389-398.

Gordon, D. V., \& Wen, J. F. (2018). Tax penalties on fluctuating incomes: Estimates from longitudinal data. International Tax and Public Finance, 25(2), 430-457.

Gowharzad, H. T., \& Al-Harthy, M. H. (2011). Production royalty sliding scales. Energy Sources, Part B: Economics, Planning, and Policy, 6(1), 53-62.

Gravelle, J. G. (2011). Reducing depreciation allowances to finance a lower corporate tax rate. National Tax Journal, 64(4), 1039.

Guo, Y., Xia, X., Zhang, S., \& Zhang, D. (2018). Environmental regulation, government $\mathrm{R} \& \mathrm{D}$ funding and green technology innovation: Evidence from China provincial data. Sustainability, 10(4), 940.

Haig Rw (1935). The cost to business concerns of compliance with tax laws. Mgnt Ree. 24, 323-333

Hofmann, E., Gangl, K., Kirchler, E., \& Stark, J. (2014). Enhancing tax compliance through coercive and legitimate power of tax authorities by concurrently diminishing or facilitating trust in tax authorities. Law and Policy, 36(3). doi: 10.1111/lapo.12021

Isehunwa, S., \& Uzoalor, E. I. (2011). Evaluation of true government take under fixed and sliding royalty scales in Nigerian oil industry. Australian Journal of Basic and Applied Sciences, 5(3), 735-741.

Johnston KS (1961) Corporations federal income tax compliance costs. Ohio University Bureau of Business Research. Monography 10. Columbus. 
Johnson, D., \& Grayson, K. (2005). Cognitive and affective trust in service relationships. Journal of Business Research, 58(4), 500-507. doi: 10.1016/ S0148-2963(03)00140-1

Kemp, A.G., (1992). Development Risks and Petroleum Fiscal Systems: A Comparative Study of the UK, Norway, Denmark and the Netherlands. Energy Journal, 13(3): $1-8$.

Kirchler, E. (2007), The economic psychology of tax behaviour, Cambridge, Cambridge University Press.

Kirchler, E., Hoelzl, E., \& Wahl, I. (2008). Enforced versus voluntary tax compliance: The "slippery slope" framework. Journal of Economic Psychology, 29(2), 210225. doi: 10.1016/j.joep.2007.05.004

Korpela, K. M., Pasanen, T. P., Repo, V., Hartig, T., Staats, H., Mason, M. \& Scopelliti, M. (2018). Environmental strategies of affect regulation and their associations with subjective well-being. Frontiers in psychology, 9, 562.

Kastlunger, B., Lozza, E., Kirchler, E., \& Schabmann, A. (2013). Powerful authorities and trusting citizens: The slippery slope framework and tax compliance in Italy. Journal of Economic Psychology, 34(2013), 36-45. doi: 10.1016/j. joep.2012.11.007

Kyari, A. K. (2013). A theoretical and empirical investigation into the design and implementation of an appropriate tax regime: an evaluation of Nigeria's petroleum taxation arrangements. (Doctoral Deseertation.Openair.rgu.ac.uk)

Lankoski, L. ( 2017). Linkages between environmental policy and competitiveness. Available online: http://www.olis.oecd.org/olis/2008doc.nsf/LinkTo/ NT0000B20E/\$FILE/JT03268619.PDF

Lee, K. (2015). Timing of penalties, tax rates, and tax evasion. FinanzArchiv: Public Finance Analysis, 71(1), 37-52.

Leeuwen, G.V.; Mohnen, P. (2013). Revisiting the Porter hypothesis: An empirical analysis of Green innovation for the Netherlands. Econ. Innov. New Technol. 67, 295-319.

Main, I. W. M. (2012). Effect of quality of service, tax sanction and costs compliance taxpayers compliance. Journal of Accounting. Udayana University. Bali.

Mas'ud, A., Aliyu, A.A., \& Gambo, E.J. (2014). Tax rate and tax compliance in Africa. European Journal of Accounting Auditing and Finance Research, 2(3), 22-30.

Mason, R., \& Calvin, L. D. (1978). A study of admitted income tax evasion. Law and Society Review, 13(Fall), 73-89.

Mayer, R. C., Davis, J. H., \& Schoorman, F. D. (1995). An integrative model of organizational trust. The Academy of Management Review, 20(3), 709-734.

Muehlbacher, S., Kirchler, E., \& Schwarzenberger, H. (2011). Voluntary versus enforced tax compliance: Empirical evidence for the "slippery slope" framework. European Journal of Law and Economics, 32(1), 89-97. doi: 10.1007/s10657011-9236-9 
Effect of Tax Rates, Penalty Rate, Detection Probability, Cost of Compliance, Royalty Rates, Environmental Regulations,

and Petroleum Profit Tax Compliance the Moderating Role of Trust in Government: A Conceptual Framework

A Conceptual Model: 71-92

Murphy, K. (2004). The role of trust in nurturing compliance: A study of accused tax avoiders. Law and Human Behavior, 28(2), 187-209. doi: 10.1023/B:LAHU.0000022322.94776.ca

Nwezeaku, N.C. (2005). Taxation in Nigeria: Principles and Practice, Owerri: Springfield Publishers Limited.

Nzioki, P. M., \& Peter, O. R. (2014). Analysis of factors affecting tax compliance in real estate sector: A case of real estate owners in Nakuru town, Kenya. Research Journal of Finance and Accounting, 5(11). Retrieved from http://www.iiste.org/ Journals/index.php/RJFA/article/view/13523

Odusola, A. (2006). "Tax policy reforms in Nigeria", World Institute for Development Economics and Research, Research Paper No. 2006/03. http://www.wider,unu. edu

Onifade, T. T. (2017). Alberta, Canada, royalty review and its lessons for resource economies. Journal of Energy \& Natural Resources Law, 35(2), 171-196

Oremade T. (2006), Petroleum Profit Tax in Nigeria. Ibadan: Evans Brothers Nigeria Publishers.

Oremade, B. T. (2010). Perception of petroleum profits tax compliance in Nigeria (Doctoral dissertation, Bournemouth University).

Osmundsen, P., (1998). Dynamic taxation of non-renewable natural resource under asymmetric information about reserves, Can. J. of Economics, 31, 933-951.

Palil, M. R., \& Mustapha, A. F. (2011). Factors affecting tax compliance behaviour in self assessment system. African Journal of Business Management, 5(33), 12864- 12872.

Park, C. G., \& Hyun, J. K. (2003). Examining the determinants of tax compliance by experimental data: A case of Korea. Journal of Policy Modeling, 25(8), 673-684.

Pommerehne, W., \& Weck-Hannemann, H. (1996). Tax rates, tax administration and income tax evasion in Switzerland. Public Choice, 88(1-2), 161-170.

Sapiei, N. S., Abdullah, M., Azmi, A. A. C., \& Mustapha, M. Z. (2017). Compliance costs and the behavior of SMEs with the implementation of GST in Malaysia. International Journal of Economics and Management, 11(S2), 379-

Savitri, E. (2016). The effect of taxpayer awareness, tax socialization, tax penalties, compliance cost at taxpayer compliance with service quality as mediating variable. Procedia-Social and Behavioral Sciences, 219, 682-687.

Schaubroeck, J., Lam, S. S. K., \& Peng, A. C. (2011). Cognition-based and affect-based trust as mediators of leader behavior influences on team performance. Journal of Applied Psychology, 96(4), 863-871. doi: 10.1037/a0022625

Sinnasamy, P., \& Bidin, Z. (2017). The relationship between tax rate, penalty rate, tax fairness and excise duty non-compliance. In SHS Web of Conferences, 34, 11001. EDP Sciences.

Slemrod, J. (1985). An empirical test for tax evasion. Review of Economics and Statistics, 67(2), 232-238. 
Slemrod, J., Blumenthal, M., \& Christian, C. (2001). Taxpayer response to an increased probability of audit: Evidence from a controlled experiment in Minnesota. Journal of Public Economics, 79(3), 455-483.

Stamatopoulos, I., Hadjidema, S., \& Eleftheriou, K. (2017). Corporate income tax compliance costs and their determinants: Evidence from Greece. In Advances in Taxation (233-270). Emerald Publishing Limited.

Tapiero, C. S. (2009) Energy consumption and environmental pollution: a stochastic model. IMA J. Manage. Math., 20, 263-273.

Torgler, B. (2011). Tax morale and compliance: Review of evidence and case studies for Europe. World Bank Policy Research Working Paper. SSRN eLibrary.

Vintilă, G., Gherghina, Ş. C., \& Păunescu, R. A. (2018). Study of effective corporate tax rate and its influential factors: Empirical evidence from emerging european markets. Emerging Markets Finance and Trade, 54(3), 571-590.

Virmani, A. (1989). Indirect tax evasion and production efficiency. Journal of Public Economics, 39(2), 223-237.

Weck-Hannemann, H., \& Pommerehne, W. (1989). Einkommenssteuerhinterziehung in der Schweiz: Eineempirische Analyse. Schweizerische Zeitschrift fu $\mathrm{Dr}$ Volkswirtschaft und Statistik, 125(4), 515-556.

Xin, M. K. H., Khai, K. G., Fong, L. S., \& Chen, N. H. (2015). Factors affecting individual taxpayers' compliance in Malaysian tax filing system. The International Journal of Business \& Management, 3(9), 339-347.

Young, J.C. (1994). Factors associated with non-compliance: Evidence from the Michigan tax amnesty program. Journal of American Taxation Association, 16(2), 82-105.

Zhao, X., \& Sun, B. (2016). The influence of Chinese environmental regulation on corporation innovation and competitiveness. Journal of Cleaner Production, 112 , 1528-1536. 